\title{
Vegetative propagation of pequi (souari nut) by cutting
}

\author{
Ricardo Neves Guimarães ${ }^{*}$ (iD) Eli Regina Barboza de Souza' ${ }^{1}$ (iD) Ronaldo Veloso Naves ${ }^{1}$ (iD) \\ Aniela Pilar Campos de Melo ${ }^{2}$ (iD) Aurélio Rubio Neto ${ }^{3}$ iD
}

${ }^{1}$ Universidade Federal de Goiás (UFG), Campus Samambaia, Rodovia Goiânia, 74690-900, Nova Veneza, Goiânia, GO, Brasil. E-mail: ricardoagroufg@hotmail.com. *Corresponding author.

${ }^{2}$ Instituto Federal Goiano (IF Goiano), Cristalina, GO, Brasil.

${ }^{3}$ Instituto Federal Goiano (IFGoiano), Polo de Inovação, Rio Verde, GO, Brasil

ABSTRACT: Pequi is propagated mainly by the seminal pathway (seminal route) and presents an uneven and reduced germination. The increasing demand for fruits and seedlings for reforestation indicate the need for new strategies for the propagation of this species which would minimize the negative impact of predatory extractivism on Caryocar brasiliense. The present study aimed to assist the development of a protocol for the cutting of the pequi tree (pequizeiro). Different ages of the matrix plant and levels of foliation and pruning were assessed through the collection (sampling) of cuttings (stakes) from plants in the field. It was noted that cuttings (stakes) from seedlings (young plants) have greater rooting capacity when compared to cuttings derived from adult plants. Pequi leafless stakes failed to root. In contrast, stakes with $50 \%$ of leaflets cut from their original size showed 2.5\% of rooting whereas those with 6 leaflets showed 22.5\% of rooting. Stakes from pruned apical branches exhibited $21.2 \%$ of rooting. Both callogenesis and rooting of pequi stakes demonstrated the potential of this particular species from the Cerrado (Brazilian savanna) for cutting.

Key words: pequi fruit (souari nut) (Caryocar brasiliense), native fructiferous species of the Cerrado (Brazilian savanna), asexual propagation.

Propagação vegetativa do pequizeiro por estaquia

RESUMO: O pequizeiro é propagado predominantemente por via seminal apresentando germinação desuniforme e reduzida. A crescente demanda por frutos e mudas para reflorestamento indicam a necessidade de novas estratégias para a propagação desta espécie, minimizando os impactos do extrativismo predatório. Objetivou-se com este estudo auxiliar no desenvolvimento de um protocolo para estaquia do pequizeiro, avaliando diferentes idades da planta matriz, niveis de enfolhamento e podas, por meio de coleta de estacas em plantas a campo. Verificou-se que estacas oriundas de plantas jovens possuem maior capacidade de enraizamento, quando comparada às estacas derivadas de plantas adultas. Estacas de pequizeiro sem folhas não enraizaram, embora estacas com 50\% de foliolos cortados do seu tamanho original apresentaram 2,5\% de enraizamento e com seis foliolos 22,5\%. Estacas oriundas de ramos apicais podados exibiram $21,2 \%$ de enraizamento. A calogênese e o enraizamento de estacas de pequi demonstram o potencial desta espécie do Cerrado para estaquia.

Palavras-chave: cerrado, frutífera nativa, propagação assexuada.

\section{INTRODUCTION}

The potential of the native fruits of the Cerrado (Brazilian savanna) has aroused the economic and financial interests in different market niches which fruits have a growing demand in Brazilian and foreign trade. Among these fruits, the pequi tree (Caryocar brasiliense Camb.) stands out due to the high economic potential of its fruit (GOMES et al., 2015; PINTO et al., 2016).

Fruits in the productive chain of the pequi are obtained by means of extractive exploration. Predatory extraction is the predominant way of collecting this species. This factor combined with the unsustainable management of native forests compromises the dissemination and propagation of this fruit in its natural habitat and promote serious environmental impacts (MOURA et al., 2013). In order to minimize the environmental impacts of predatory extraction, one of the alternatives would be the commercial cultivation of pequi tree. However, for the domestication of this species and its subsequent commercial cultivation, it is fundamental to understand its propagation process. This would be the first stage to overcome especially with regard to the vegetative propagation.

The planting of pequi seedlings produced by the seminal route still the most widespread pathway. However, the low germination percentage due to the natural dormancy of the seeds (SOUZA et 
al., 2017) limits the propagation of this species on a large scale. In order to potentiate and standardize the germination of pequi by the seminal route, different techniques have been used, including the removal of germination inhibitory coatings, seed scarification, and use of gibberellic acid (BERNARDES et al., 2008; LEAO et al., 2012 ).

Among techniques of vegetative propagation of pequi, cuttings may become a promising alternative for the vegetative propagation of this tree in the near future. It is a low cost, fast and simple technology that can provide large-scale production of seedlings. The use of vegetative propagation is restricted to reports of Brazilian native species and have not been reported for the pequi tree (DIAS et al., 2012).

In view of the above-mentioned, the present study aimed to establish the basis for pequi tree.Cutting of this tree at different ages, pruning of the matrix plant, and levels of stem formation from matrices present in the field were the parameters evaluated in this study.

\section{MATERIALS AND METHODS}

Tests were conducted in an oven (area of $42 \mathrm{~m}^{2}$ and height of $4 \mathrm{~m}$ ), protected at the top and sides by white plastic $150 \mu$ thick. The fogging system was of the intermittent type, was controlled by a timer, was triggered from $7 \mathrm{am}$ to $7 \mathrm{pm}$, was activated every minute, and had an irrigation period of $45 \mathrm{~s}$ to maintain the relative humidity close to $90 \%$.

The cuttings were collected in the morning to avoid dehydration, and were then stored in pails (buckets) with water for maintenance of turgescence. No fungicide treatment was used so that the cuttings could express their rhizogenic potential. A preventive measure implemented to eliminate pathogens and inoculum sources consisted of periodic (regular) hygienization of the greenhouse. Fungicide was not applied on the cuttings.

\section{Assay 1 - Influence of age and levels of soil degradation for pequi cuttings}

Herbaceous cuttings were collected from different matrix plants of 6-year-old juvenile young adults and 22-year-old adult plants from the municipality of Goiânia, State of Goiás, Central, West Brazil (16 35' 59' S, 49 16'44" 'W, 872m). Apical herbaceous cuttings originating from non-lignified shoots of the year were collected. These specimens had lengths varying between $10 \mathrm{~cm}$ and $19 \mathrm{~cm}$ and diameters ranging between $0.5 \mathrm{~mm}$ and $0.8 \mathrm{~mm}$.

The cuttings had up to 2 buds and were harvested from branches of the first flow of budding from the basal and median region of the crown. Stakes from three different types of soil were evaluated as follows: stakes prepared with 6 leaflets; 6 leaflets cut at $50 \%$ of their original size; and cuttings without leaflets. The cuttings were inserted in tubes $\left(260 \mathrm{~cm}^{3}\right)$ containing coconut fiber.

The experimental design was completely randomized in a factorial scheme $3 \times 2$, with 3 types of matting and 2 ages of the matrices with 4 replications of 5 stakes totaling 120 stakes. After 42 days of testing, the percentage of live cuttings, cuttings with calluses and root primordia (roots from $1 \mathrm{~mm}$ in length) were assessed.

\section{Assay 2 - Levels of foliation in young plants on trees with and without pruning for pequi cuttings}

Non-pruned and pruned plants were selected in the median and basal region of the crown. With the aid of a pruning shear, apical shoots from the last bud flow with a diameter ranging from $5 \mathrm{~mm}$ to $10 \mathrm{~mm}$ were removed. The stakes of pruned branches presented potential for cuttings after 144 days of pruning. Herbaceous cuttings were selected with 1 and 2 pairs of pruned tree leaves and without any pruning harvested from branches of the first bud flow of the median and basal regions of the crown. Leaflets of the cuttings were reduced to $50 \%$ of their original size.

Cuttings had the following characteristics: 1 or 2 buds, lengths ranging from $5 \mathrm{~cm}$ and $32 \mathrm{~cm}$ and diameters varying between $5 \mathrm{~mm}$ and $15 \mathrm{~mm}$. The experimental design was completely randomized in a $2 \times 2$ factorial scheme with two different types of vegetation ( 1 or 2 pairs of leaves) and two different types of pruning (with and without pruning) with 4 replications and 10 cuttings per plot resulting in a total of 160 stakes. Cuttings were inserted in tubes $\left(260 \mathrm{~cm}^{3}\right)$ containing coconut fiber. After 64 days of the assay implementation, the percentage of live cuttings, cuttings with calluses, rooted cuttings (roots from $5 \mathrm{~mm}$ in length), and number and length of roots per cutting were evaluated.

The significance of the effect of the treatments was estimated using the F-Test, and the means were compared using the Scott-Knott test $(\mathrm{P}<0.05)$.

\section{RESULTS AND DISCUSSION}

\section{Assay 1 - Influence of age and levels of foliation for pequi tree cutting \\ An interaction between the factors} "plant age" and "soil level" was observed only for the variable percentage of live cuttings. The age of the plants influenced the calogenesis process. The 
percentage of calli was higher in cuttings originating from young plants. However, the formation of the root primordia was not affected by this factor as shown in table 1 .

The level of foliation of stakes directly affected calogenesis and rooting (Table 1). Stakes with 6 leaflets and 6 leaflets cut at $50 \%$ of their original size allowed the formation of 35.00 and $32.50 \%$ of calli, respectively, and did not differ from each other. However, they differed from cuttings without leaflets that did not form calli. In stakes with 6 leaflets, a higher percentage of root primordia was observed $(22.50 \%)$ differing from cuttings with 6 leaflets cut to $50 \%$ of their original size with $2.50 \%$ and without leaflets and without root primordia formation. The absence (lack) of leaves resulted in $100 \%$ mortality of the cuttings.

With regard to the percentage of live cuttings, an interaction between the factor studied was observed (Table 1). The levels of young leaf cuttings with 6 leaflets (folioles) and 6 leaflets (folioles) cut at $50 \%$ of their original size obtained higher survival rates with 90.0 and $60.0 \%$ respectively, differing statistically from the cuttings of adult plants with 6 and 6 cut leaflets to $50 \%$ with 35.0 and $20.0 \%$ survival, respectively (Table 2 ).

The age of the matrix plant determines the vegetative propagation through cuttings.

XAVIER et al. (2013) reported that the cloning of adult plants would be ideal since these plants can express all their productive potential unlike young plants. However, young plant cuttings provided

Table 1 - Percentage of cuttings (stakes) with callus (CL) and root primordia (RP) of Caryocar brasiliense Camb., from cuttings of young plants and adult plants with different levels of foliation.

\begin{tabular}{lcc}
\hline Treatments & $\% \mathrm{CL}$ & $\% \mathrm{RP}$ \\
\hline Plant age (A) & & \\
Adult & $10.00 \mathrm{~b}$ & $5.00 \mathrm{a}$ \\
\hline Young & $35.00 \mathrm{a}$ & $11.66 \mathrm{a}$ \\
\hline F Test & $7.94^{*}$ & $2.66 \mathrm{~ns}$ \\
\hline Foliation (F) & & \\
\hline 6 folioles & $35.00 \mathrm{a}$ & $22.50 \mathrm{a}$ \\
\hline $50 \%$ of folioles & $32.50 \mathrm{a}$ & $2.50 \mathrm{~b}$ \\
\hline Without folioles & $0.00 \mathrm{~b}$ & $0.00 \mathrm{~b}$ \\
\hline F Test & $6.45^{* *}$ & $12.16^{* *}$ \\
\hline
\end{tabular}

Means followed by the same letter do not differ from each other by the Scott-Knott test $(\mathrm{P}>0.05) .{ }^{*}$ significant $(\mathrm{P}>0.05)$;

${ }^{* *}$ significant $(\mathrm{P}<0.01)$; ns - not significant.
$90.0 \%$ of survival in plants with 6 leaflets and also had $35.0 \%$ of callogenesis (Table 2). A higher percentage of rooting was also observed in stakes of young plants $(11,66 \%)$ after 42 days of research.

Difficult-to-root stakes originating from adult plants was also reported by GRATIERISOSSELLA et al. (2008) in studies with Erythrina velutina Willd. After stakes were collected in the field in matrices of different ages, the authors observed that after 30 days, stakes of adult plants ( $>15$ years) failed to root, and that rooting was observed in only $1.4 \%$ of young 1-year-old plants. Stakes collected from adult plants have lower levels of endogenous auxin in comparison with young matrices which result in smaller percentages of rooting. Despite the low percentage of rooting in adult pequi plants, the potential of pequi tree to form stakes should be emphasized as rooting occurred in adult stakes and in young stakes as well.

LATTUADA et al. (2011) evaluated the influence of age on formation of herbaceous stakes of Eugenia uniflora L. These researchers observed that after 70 days of study stakes of 3-year-old plant young plants exhibited $7,6 \%$ of callogenesis and $36 \%$ of rooting whereas stakes obtained from 10-year-old adult plants failed to root. Propagules obtained from young plants have high rhizogenic potential. There is a tendency to reduce such potential as the matrix plant ages.

With respect to the levels of foliation, we demonstrated the importance of the leaves in the formation of calluses and in the first stages of the rhizogenic process. Lack of leaves in stakes resulted in $100 \%$ mortality of pequi stakes. According to XAVIER et al. (2013), the leaf is critical to the rhizogeric process as this organ provided the plant with hormones and carbohydrates. Auxins mantain cells viable during the rhizogenic process; however, the levels of these hormones vary between species and genotypes (CHIAMOLERA et al., 2014) whereas carbohydrates are essential for the survival of the stakes as they provide physiological conditions that are necessary for rhizogenesis (SPANDRE et al., 2012).

Foliation levels during the rooting process of herbaceous stakes of the common guava (Psidium guajava L.) which is an evergreen shrub propagated on a commercial scale through stakes was studied by SANTORO et al. (2010). Similarly, these authors observed a $100 \%$ mortality of leafless stakes. However, the presence of entire leaves resulted in $75 \%$ of rooting which suggested that leafless stakes have low levels of endogenous auxins which are 
Table 2 - Percentage of live cuttings (EV) of Caryocar brasiliense Camb., influenced by the presence of leaves (F) as a function of different ages of the matrices $(\mathrm{M})$.

\begin{tabular}{|c|c|c|c|}
\hline Biological age & 6 folioles & $50 \%$ of folioles & Absence (Lack) of folioles \\
\hline Adults & $35.00 \mathrm{bA}$ & $20.00 \mathrm{bA}$ & $0.00 \mathrm{aA}$ \\
\hline Young & $90.00 \mathrm{aA}$ & $60.00 \mathrm{aB}$ & $0.00 \mathrm{aC}$ \\
\hline Interaction $(\mathrm{M} \times \mathrm{F})$ & $4.09^{*}$ & & \\
\hline $\mathrm{CV} \%$ & 58.13 & & \\
\hline
\end{tabular}

Means followed by the same letter do not differ from each other by the Scott-Knott test $(\mathrm{P}>0.05) .{ }^{*}$ significant $(\mathrm{P}<0.05)$.

insufficient to rooting. Therefore, leaf retention is essential for the rhizogenesis as it keeps stakes alive.

Excessive transpiration interferes with the formation of calluses and adventitious roots. The pequi has large leaves $(20 \mathrm{~cm}$ in length and $15 \mathrm{~cm}$ wide) with petioles that may reach up to $15 \mathrm{~cm}$ and petiolules that may reach up to $2 \mathrm{~cm}$ (KUHLMANN, 2012). The highest percentage of survival of young and adult pequi stakes with 6 leaflets indicated that there was no excessive transpiration of leaves. Our finding corroborated the one published by LUSA \& BIASI (2011) in stakes of Cuphea calophylla Cham. $\&$ Schltdl.

Leaf retention of pequi has a positive correlation with the process of callogenesis and later formation of adventitious plant roots. Stakes with 6 leaflets and 6 leaflets cut to $50 \%$ of its original size presented $35.00 \%$ and $32.50 \%$ of callogenesis, respectively. Due to its size, pequi stakes are more fragile than many other plant species. Therefore, number of leaflets must be optimized. Stakes with 6 leaflets cut at $50 \%$ of their original size have been reported to be simpler to handle. These stakes take less physical space, As a result, an increase in stakes per tray is observed. Cuttings (stakes) with 6 leaflets showed faster rooting with $22.50 \%$ of root primordia but occupied more production space.

It should be emphasized that young plant cuttings (stakes) with 6 leaflets cut at $50 \%$ of their original size presented only $2.50 \%$ of root primordia. In contrast, $32.50 \%$ of the calli were alive and had rooting potential in longer studies. The formation of an indirect adventitious root system was observed in pequi stakes. According to XAVIER et al. (2013), indirect rooting occurs because initially there is the formation of calli in the stakes and later the formation of root primordia. The presence of calli signals the formation of adventitious roots (SILVA et al., 2012).
Assay 2 - Levels of foliatiom in young plants on trees with and without pruning for pequi tree cutting (stakes)

There was no interaction between the factors "foliation" and "pruning" for all variables. Therefore, the variables were analyzed considering the means of each factor (Table 3).

The foliation level did not affect the percentages of live cuttings (stakes) with calli and roots or the number and length of the roots. These results are not in accordance with those published by STUEPP et al. (2014). These authors describe an association between increased leaf numbers and transpiration levels on cuttings (stakes). According to these researchers, increased transpiration reduces rooting and; therefore, decreases stake (cutting) survival. In eucalyptus, excessive transpiration is considered one of the main mortality factors of minicuttings (BATISTA et al., 2014). These results showed that a pair of leaves is sufficient to induce rooting in pequi stakes.

A smaller number of leaves per stake facilitate handling of the propagule without causing physiological damage. There was the development of a fascicular root system consisting of primary roots originated from the neck region which is characteristic of those species propagated by cuttings (XAVIER et al. 2013).

Pruning is an efficient resource for obtaining pequi stakes for rhizogenesis. Pruning the apical buds was an alternative that induced axillary shoot formation which is an important feature that enhanced the cutting technique of this native species.

The formation of new shoots in pruned branches were vigorous and physiologically suitable for vegetative propagation by cutting 144 days postpruning. Hormones and carbohydrates accumulated in the newly formed shoots are fundamental to the 
Table 3 - Percentages of live cuttings (LC), cuttings with calli (CC), rooted stakes (RS), mean number of roots per stake (NR), average length of the three largest cuttings (TC) of Caryocar brasiliense Camb. under the influence of the presence of leaves in pruned plants and non-pruned plants.

\begin{tabular}{|c|c|c|c|c|c|}
\hline Treatments & $\% \mathrm{LC}$ & $\% \mathrm{CC}$ & $\% \mathrm{RS}$ & NR & TC \\
\hline \multicolumn{6}{|c|}{ 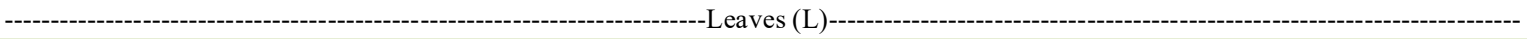 } \\
\hline 1 pair of leaves & $65.00 \mathrm{a}$ & $45.00 \mathrm{a}$ & $20.00 \mathrm{a}$ & $1.36 \mathrm{a}$ & $0.90 \mathrm{a}$ \\
\hline 2 pairs of leaves & $50.00 \mathrm{a}$ & $38.75 \mathrm{a}$ & $11.25 \mathrm{a}$ & $1.11 \mathrm{a}$ & $0.74 \mathrm{a}$ \\
\hline F test & $2.37 \mathrm{~ns}$ & $0.75 \mathrm{~ns}$ & $2.77 \mathrm{~ns}$ & $0.23 \mathrm{~ns}$ & $0.15 \mathrm{~ns}$ \\
\hline \multicolumn{6}{|c|}{ 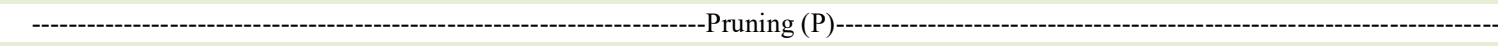 } \\
\hline Pruned & $51.25 \mathrm{a}$ & $40.00 \mathrm{a}$ & $21.25 \mathrm{a}$ & $1.84 \mathrm{a}$ & $1.10 \mathrm{a}$ \\
\hline Non-pruned & $63.75 \mathrm{a}$ & $43.75 \mathrm{a}$ & $10.00 \mathrm{a}$ & $0.63 \mathrm{~b}$ & $0.54 \mathrm{a}$ \\
\hline F test & $1.64 \mathrm{~ns}$ & $0.27 \mathrm{~ns}$ & $4.58 \mathrm{~ns}$ & $5.42^{*}$ & $1.95 \mathrm{~ns}$ \\
\hline $\mathrm{CV}(\%)$ & 33.86 & 34.30 & 67.25 & 83.52 & 96.72 \\
\hline
\end{tabular}

Means followed by the same letter do not differ from each other by the Scott-Knott test $(\mathrm{P}>0.05) .{ }^{*}$ significant $(\mathrm{P}<0.05)$; ns - not significant.

beginning of the rhizogenic process (STENVALL et al., 2009). This increase in the concentration of auxins and carbohydrates may have contributed to the rooting of $21.25 \%$ of cuttings (stakes) with pruning in comparison with the $10.00 \%$ in cuttings (stakes) obtained from branches without pruning.

Even though there was no difference between pruned branches and non-pruned branches, the percentages of callogenesis of $40.00 \%$ and $43.75 \%$ showed the potential of the pequi tree for cuttings indicating the production of auxins and carbohydrates in these branches. Cutting potentiation can be obtained using different techniques such as rejuvenation. In the present study, this technique was performed by pruning apical buds inducing the formation of new shoots in trees in the field. Thus, pruning of pequi trees caused an increase in the average number of roots in cuttings.

WENDLING et al. (2015) studied the induction of shoot formation in adult matrices of Araucaria angustifolia (Bertol.) Kuntze 1898. These researchers also noted that the induction of shoot formation by pruning adult plant branches provides a high potential for vegetative propagation by the cutting method.

Another determinant factor was the collection (sampling) of pequi tree cuttings in 6-yearold trees in the field, trees at the early stages of the productive process, and in the transition from the juvenile stage to the adult stage in which the desirable characteristics such as production precocity, size, and color of fruits were already present. However, this transition is complex and may interfere with the rhizogenic process as a result of biochemical changes (XAVIER et al., 2013).

\section{CONCLUSION}

Propagation of the pequi tree by means of cuttings is a viable process. The maintenance of the leaves in stakes is fundamental for their rhizogenesis since leafless stakes are unable to root. Stakes from pruned young plants (apical branches) are the most suitable for pequi cuttings.

\section{DECLARATION OF CONFLICTING INTERESTS}

The authors declare no conflict of interest.

\section{ACKNOWLEDGMENTS}

We gratefully acknowledge CAPES that provided scholarships to Ricardo Neves Guimarães and Aniela Pilar Campos de Melo PhD students and authors of this article. All authors contributed equally for the conception and writing of the manuscript. All authors critically revised the manuscript and approved of the final version.

\section{REFERENCES}

BATISTA, A. F. et al. Influence of leaf architecture of minicuttings in clonal propagation of Eucalyptus. Revista Árvore, v. 38, n. 5, p. 819-827, 2014. Available from: <http://dx.doi.org/10.1590/S010067622014000500006>. Accessed: Jan. 7, 2018. doi: 10.1590/ S0100-67622014000500006.

BERNARDES, T. G. et al. Sexed propagation of pequi (Caryocar brasiliense Camb.) induced by gibberellic acid. Pesquisa 
Agropecuária Tropical, v. 38, n. 2, p. 71-77, 2008. Available from: $<$ https://www.revistas.ufg.br/pat/article/view/4154>. Accessed: Jan. 7, 2018.

CHIAMOLERA, F. M. et al. Cloning of yellow sapote by cutting. Revista Brasileira de Fruticultura, v. 36, n. 3, p. 649-654, 2014. . Available from: <http://dx.doi.org/10.1590/0100-2945-312/13> Accessed: Jan. 7, 2018. doi: 10.1590/0100-2945-312/13.

DIAS, P. C. et al. Cutting and mini-cutting techniques of Brazil wood species. Pesquisa Florestal Brasileira, v. 32, n. 72, p. 453-462, 2012

GOMES, S. O. et al. Prospecção Tecnológica: Potencialidades do uso do pequizeiro (Caryocar spp.). GEINTEC - Gestão, Inovação e Tecnologias, v. 1, n. 5, p. 1617-1625, 2015.

GRATIERI-SOSSELLA, A. et al. Propagation of swamp corticeira (Erythrina crista-galli L.) (Fabaceae) by the cutting technique. Revista Árvore, v. 32, n. 1, p. 163-171, 2008. Available from: <http://dx.doi.org/10.1590/S0100-67622008000100018>. Accessed: Jan. 7, 2018. doi: 10.1590/S0100-67622008000100018.

KUHLMANN, M. Frutos e sementes do Cerrado atrativos para a fauna. Brasília: Rede de Sementes do Cerrado, 2012. 360 p.

LATTUADA, D. S. et al. Pre-treatments with water and indole butyric acid dosis for herbaceous cuttings of Surinam cherry. Ciência Rural, v. 41, n. 12, p. 2073-2079, 2011. Available from: <http:// dx.doi.org/10.1590/S0103-84782011001200006>. Accessed: Jan. 7, 2018. doi: 10.1590/S0103-84782011001200006.

LEAO, E. F. et. al. Seedling emergence of Caryocar brasiliense according to mother plant and gibberellic acid use. Pesquisa Agropecuária Tropical, v. 42, n. 4, p. 416-423, 2012. Available from: <https://dx.doi.org/10.1590/S1983-40632012000400009>. Accessed: Jul 21, 2018. doi: 10.1590/S1983-40632012000400009.

LUSA, M. G; BIASI, L. A. Cutting of Cuphea calophylla subsp. mesostemon (Koehne) Lourteig (Lythraceae). Revista Brasileira de Plantas Medicinais, v. 13, n. 1, p. 52-57, 2011. Available from: $<$ http://dx.doi.org/10.1590/S1516-05722011000100008>. Accessed: Jan. 7, 2018. doi: 10.1590/S1516-05722011000100008.
MOURA, N. F. et al. Characterization of pequi fruits (Caryocar brasiliense Camb.) from Brazilian cerrado. Revista Árvore, v. 37, n. 5, p. 905-912, 2013. Available from: <http://dx.doi. org/10.1590/S0100-67622013000500013>. Accessed: Jan. 7, 2018. doi: 10.1590/S0100-67622013000500013.

SANTORO, P. H. et al. Influence of leaf and base lesion of herbaceous cutting in the guava rooting of the selection 8501-9. Semina: Ciências Agrárias, v. 31, n. 2, p. 289-294, 2010.

SILVA, L. F. O. et al. Rooting of semi-woody cuttings of olive cultivars. Bragantia, v. 71, n. 4, p. 488-492, 2012.

SOUZA, A. M. S. et al. Structural aspects of germination control in pyrenes of Caryocar brasiliense (Caryocaraceae). Trees, v. 31, n. 3, p. 887-902, 2017. Available from: <https://doi.org/10.1007/ s00468-016-1514-2>. Acessed: Jul 21, 2018. doi: 10.1007/s00468016-1514-2.

SPANDRE, P. et al. Stem cuttings of "guaçatonga" (Casearia sylvestris Swartz) in the four seasons of the year with the use of different IBA concentrations. Revista Brasileira de Plantas Medicinais, v. 14, n.3, p. 529-536, 2012.

STENVALL, N. et al. Seasonal fluctuation of root carbohydrates in hybrid aspen clones and its relationship to the sprouting efficiency of root cuttings. Canadian Journal of Forest Research, v. 39, p. 1531-1537, 2009. Available from: < https://doi.org/10.1139/X09066>. Accessed: Jan. 7, 2018. doi: 10.1139/X09-066.

STUEPP, C. A. et al. Vegetative propagation of mature dragon trees through epicormic shoots. Bosque, v. 35, n. 3, p. 337345, 2014. Available from: <http://www.redalyc.org/articulo. oa? $\mathrm{id}=173133052008>$. Accessed: Jan. 7, 2018.

WENDLING, I.; BRONDANI, G. E. Vegetative rescue and cuttings propagation of Araucaria angustifolia (Bertol.) Kuntze. Revista Árvore, v. 39, n. 1, p. 93-104, 2015.

XAVIER, A. et al. Silvicultura Clonal: princípios e técnicas. 2. ed. Editora UFV: Viçosa, 2013. 279p. 